\title{
Population Development and the Changes in the Economic Structure of Finnish Urban Areas
}

\author{
MARIE REIJO \\ Research Associate \\ Academy of Finland \\ Helsinki, Finland
}

\section{TAPANI VALKONEN}

Research Professor

Academy of Finland

Helsinki, Finland

\begin{abstract}
This article describes population development in urban communities and differences therein found during the period 1975-1990. The causes behind these differences are analyzed by using data on the economic development of the communities (e.g. the changes in industry and unemployment). Economic development in 1975-90 is linked to the regional transition in labor distribution and industrial activity, with a focus on deindustrialization and the growing predominance of the service sector in the trade structure. Using a community typology compiled on the basis of the analyses, estimates are made of future development in various communities up to the year 2010.

The article will present the main results of a study which comprises the demographical portion of a multidisciplinary Finnish research program entitled "Prospects for Finnish Localities".
\end{abstract}

Keywords: population development, economic changes, urban areas, Finland

This article will present the main results of a study called "Community Population Development and the Changes in the Economic Structure" carried out at the Department of Sociology of the University of Helsinki. This study comprises the demographical portion of a multidisciplinary Finnish research program entitled "Prospects for Finnish Localities" encompassing seven subprojects focusing on structural changes in Finnish communities. (Andersson et al. 1991.)

The article will describe population development in urban communities and differences therein found in communities during the period 1975-1990. We will then analyze the causes behind these differences by using data on the economic development of the communities (e.g. the changes in industry and unemployment). Economic de- 
velopment in 1975-90 is linked to the regional structuring in labor distribution and industrial activity, with a focus on deindustrialization and the growing predominance of the service sector in the trade structure. Using a community typology compiled on the basis of the analyses, estimates are made of future development in various communities up to the year 2010.

This article will concentrate on the main results of the study, which have been reported more fully in the main report of the Finnish study (Reijo 1993). The main report also describes the data and methods in more detail.

\section{Carrying out the study}

In research on population development in urban communities, it is not practical to have urban municipalities be the units of observation according to their administrative boundaries, instead broader urban areas should be used, so that the effects of the growth of an urban area on the statistics being examined can be taken into account. The units of observation in the study were the urban areas of Finland, which were defined according to their activity base in broader terms than cities as urban labor market areas. These units of observation correspond to the localities in the research program's framework (e.g. Andersson et al. 1991). The population of the urban labor market areas has spread from the cities to the surrounding municipalities, whose inhabitants are employed to a great extent in centers of employment outside their own county of residence. Jobs and thus the daytime population are concentrated in these centers. A large share of the population in the surrounding municipalities are members of the nighttime or resident population.

A total of 41 urban areas delineated by municipality groups has been demarcated by Marja-Liisa Anttalainen (1990) (Figure 1). Each urban area delineated by municipality groups (hence abbreviated as urban municipality group) is composed of an $u r$ ban center municipality and usually also of one or more surrounding urban municipality. The criteria for demarcating the urban center municipalities have been the size of the population (almost all had more than 20,000 residents) and the density of apartment buildings (at least $40 \%$ of housing). The criterion for demarcating the surrounding urban municipalities was substantial commuting to the urban center municipalities. At least $20 \%$ of the labor force of the surrounding urban municipalities was employed in the urban center municipality in their area - at its highest, this proportion rose to $60 \%$. In $199068 \%$ of the Finnish population lived in urban municipality groups.

In addition to the urban municipality groups, the study also examines other municipality groups. In the next zone around the urban municipality groups surrounding municipalities were distinguished, from which commuting was almost as common as in the surrounding urban municipalities. The surrounding municipalities differed from the surrounding urban municipalities, however, in that they were not as dependent on the city in the center as an area of employment. People living in the surrounding municipalities were employed both in the urban center municipality and generally also in the surrounding urban municipalities. The municipalities outside the urban municipality groups (i.e. urban center municipalities and the surrounding municipalities) are called peripheral municipalities.

The basic data of the study were the population statistics for each municipality, census data and labor force data for the period 1975-1990 and population and labor force forecasts to the year 2010. The population forecasts used were both the calculation including and excluding migration compiled by Statistics Finland (Väestö 1992:6), where the population development of 1987-1989 has been projected into the future. The data was obtained from the regional data base (Altika) and official publications. 
Fig u re 1. The urban areas delineated by municipality groups (urban municipality groups). ${ }^{1}$ The urban center municipalities are colored in black and the surrounding urban municipalities in gray.

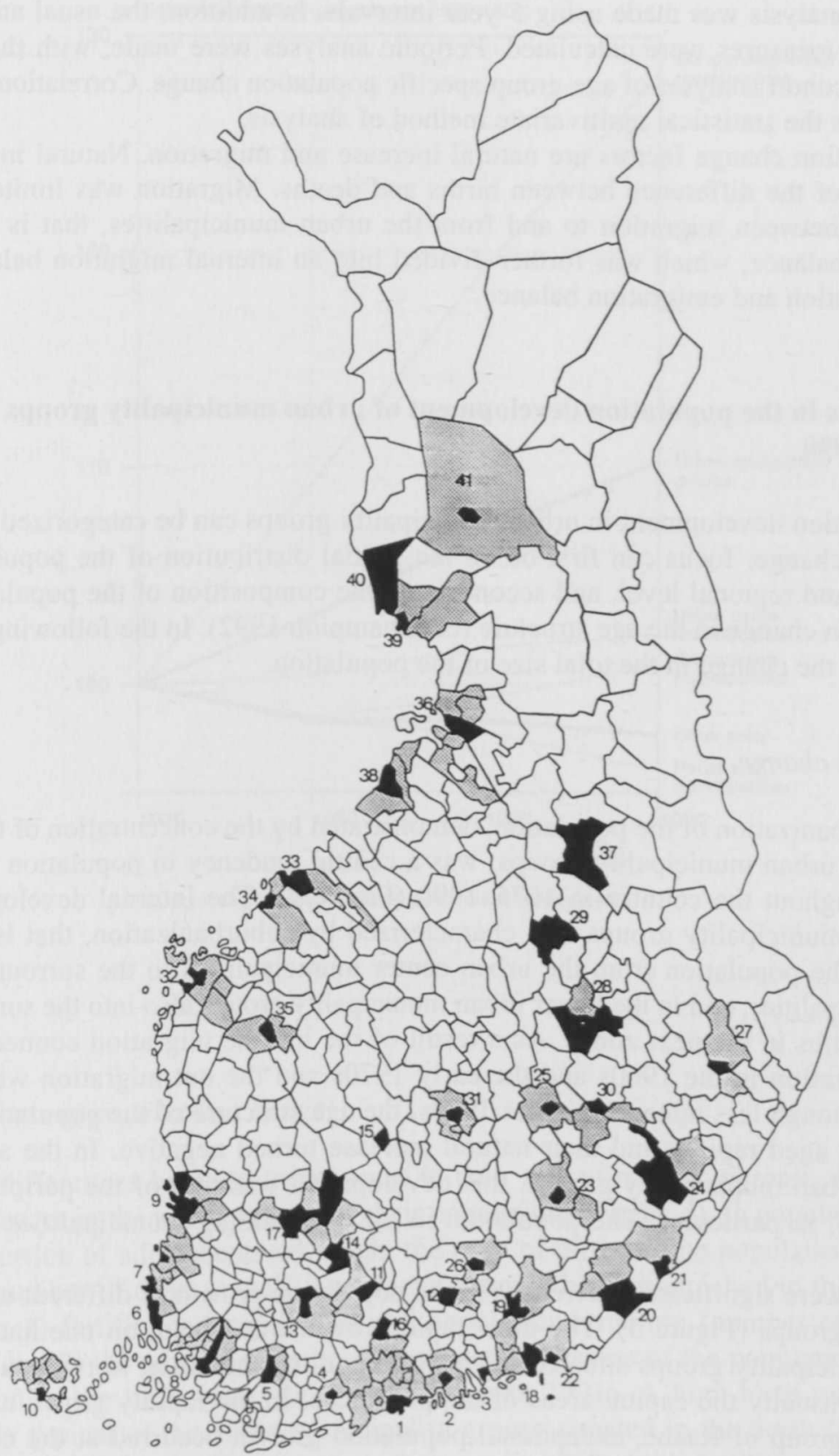

1 Helsinki, 2 Porvoo, 3 Loviisa, 4 Lohja, 5 Salo, 6 Uusikaupunki, 7 Rauma, 8 Turku, 9 Pori, 10 Mariehamn, 11 Hämeenlinna, 12 Lahti, 13 Forssa, 14 Valkeakoski, 15 Mänttä, 16 Riihimäki, 17 Tampere-Nokia, 18 Kotka, 19 Kouvola-Kuusankoski, 20 Lappeenranta, 21 Imatra, 22 Hamina, 23 Mikkeli, 24 Savonlinna, 25 Pieksämäki, 26 Heinola, 27 Joensuu, 28 Kuopio, 29 Iisalmi, 30 Varkaus, 31 Jyväskylä, 32 Vaasa, 33 Kokkola, 34 Pietarsaari, 35 Seinäjoki, 36 Oulu, 37 Kajaani, 38 Raahe, $39 \mathrm{Kemi}, 40$ Tornio, 41 Rovaniemi 
The labor force forecasts were the basic Labor Force 2000 calculation (Työvoima 2000) and alternative calculations compiled by the Ministry of Labor (1992).

Population development was analyzed using a decomponization method, where relative population growth was broken up into the sum of its components. The population transition analysis was made using 5-year intervals. In addition, the usual annual demographic measures were calculated. Periodic analyses were made, with the exception of the cohort analyses of age-group-specific population change. Correlation analysis was used as the statistical multivariate method of analysis.

Population change factors are natural increase and migration. Natural increase is composed of the difference between births and deaths. Migration was limited to the difference between migration to and from the urban municipalities, that is the total migration balance, which was further divided into an internal migration balance and an immigration and emigration balance.

\section{Differences in the population development of urban municipality groups in $\mathbf{1 9 7 5 - 1 9 9 0}$}

Population development in urban municipality groups can be categorized into two groups of change: focus can first be on the spatial distribution of the population on the urban and regional level, and secondly, on the composition of the population, for example, on change in the age structure (cf. Champion 1992). In the following we will begin with the change in the total size of the population.

\section{Population change}

The urbanization of the population, demonstrated by the concentration of the population into urban municipality groups, was a central tendency in population development throughout the country in 1975-1990 (Figure 2). The internal development of the urban municipality groups was characterized by suburbanization, that is the diffusion of the population from the urban center municipalities to the surrounding urban municipalities, and in the larger urban municipality groups also into the surrounding municipalities in the next zones. As a result of the intense migration connected with industrialization in the 1960 s and the early 1970 s and the out-migration which continued, although less intensely, in the 1980 s, the age structure of the population in the rural areas aged rapidly and their natural increase turned negative. In the areas outside the urban municipality groups, this development was true of the peripheral municipalities, in particular. The population in the surrounding municipalities began to grow.

There were significant differences in the population growth of different urban municipality groups (Figure 3 ). The most rapid growth was found, on one hand, in the urban municipality groups situated in Uusimaa and, on the other, in regional centers, which are usually the capital areas of the provinces. In the rapidly grown urban municipality group of Rahe, exceptional population growth occurred at the end of the 1970 s, and in the latter half of the 1980s the population began to decline. In 1975-90 population loss was felt by some urban municipality groups and small industrial communities situated in southeastern Finland. The population again began to concentrate in the large population centers in the 1980 s, which had been preceded by a phase in stabilization of population growth differences at the end of the 1970s. 
Fi g u r e 2. Relative population change in 1975-90 in the urban municipality groups, areas outside the urban municipality groups and in the entire country. (Population in 1975 is equal to 100.)

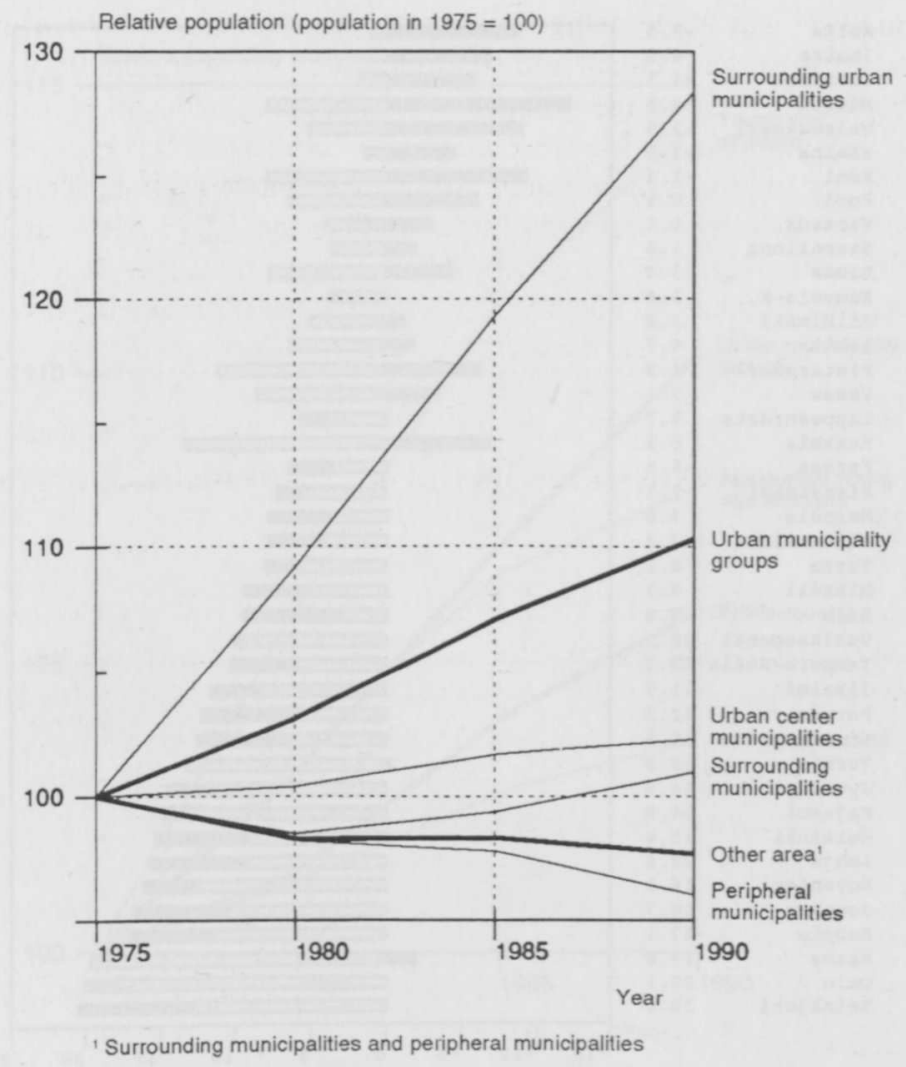

\section{Components of population change}

The differences between urban areas in their rate of natural increase were caused by differences in the age structures of their populations (Figure 4). In populations where the proportion of adolescents was high, the ratio of births to the population was large and the number of deaths small. Two factors should be distinguished in the birth rate, however: 1) fertility independent of the population structure (number of births per woman) and 2) the advantageousness/disadvantageousness of the population structure in relation to the birth rate. (Reijo and Valkonen 1991). A high birth rate has been especially typical of the urban municipality groups situated in the north (Raahe, Pietarsaari, Oulu, Kokkola, Tornio, etc.). As a result of the high fertility, the age structure of the population in these urban areas has been young, excluding communities (for example, Kemi), where population losses substantially decreased the young adult population. In some urban municipality groups, though, (in Helsinki and Kuopio, for example) fertility was relatively low, but due to migration gains, the proportion of the population of childbearing age and thus the number of births was high (that is, the population structure was advantageous for the birth rate). 
Fig u r e 3. Population growth in urban municipality groups (in figures), natural increase and total balance of change (\%) in 1975-90

Population growth \%

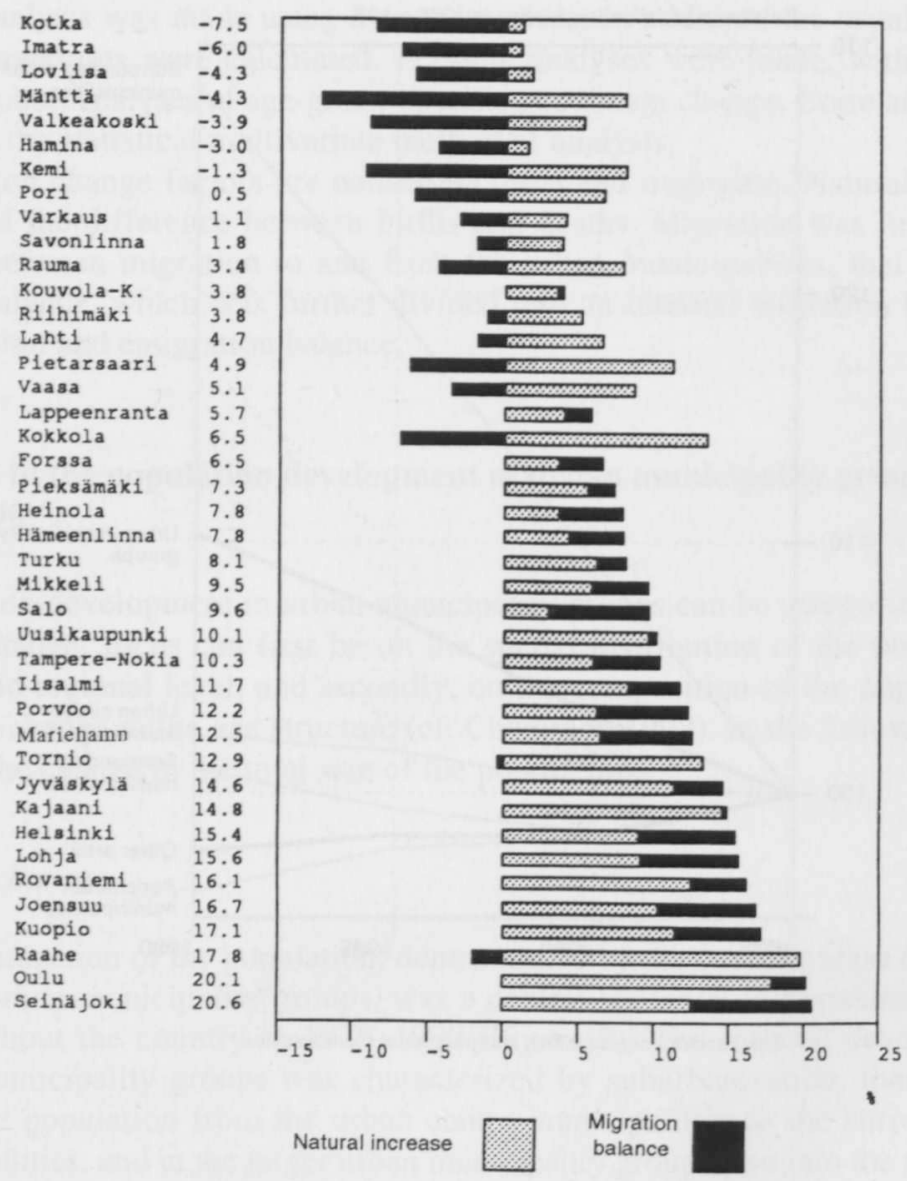

In urban municipality groups with an old age structure, mortality per 1,000 inhabitants was high, which contributed to decreasing their population growth. Age-specific mortality varied so little between urban municipality groups, that it had no significant effect on the differences in population development (Reijo and Valkonen 1992).

A clear distinction between the effect of natural increase and migration on total population development cannot be made in the long run, for migration gain also may increase natural increase. Migrants are young adults and in the areas of migration gain the number of potential childbearers rose. If, at the same time, the number of children per woman was already high, as in, for example the urban municipality groups of Rovaniemi and Oulu, natural increase was extremely rapid. But in areas of population loss, the number of women of childbearing age declined. The most rapid decrease in population among the urban municipality groups with population loss was found in areas where the number of children per woman, i.e. fertility, was low (in Kotka and Loviisa, for example). 
Fig u re 4. The relative population growth in urban municipality groups according to the youth of the age structure (proportion of the population under 55 years of age $)^{1}$ and the population growth of the entire country in 197590 (population in 1975 is equal to 100 )

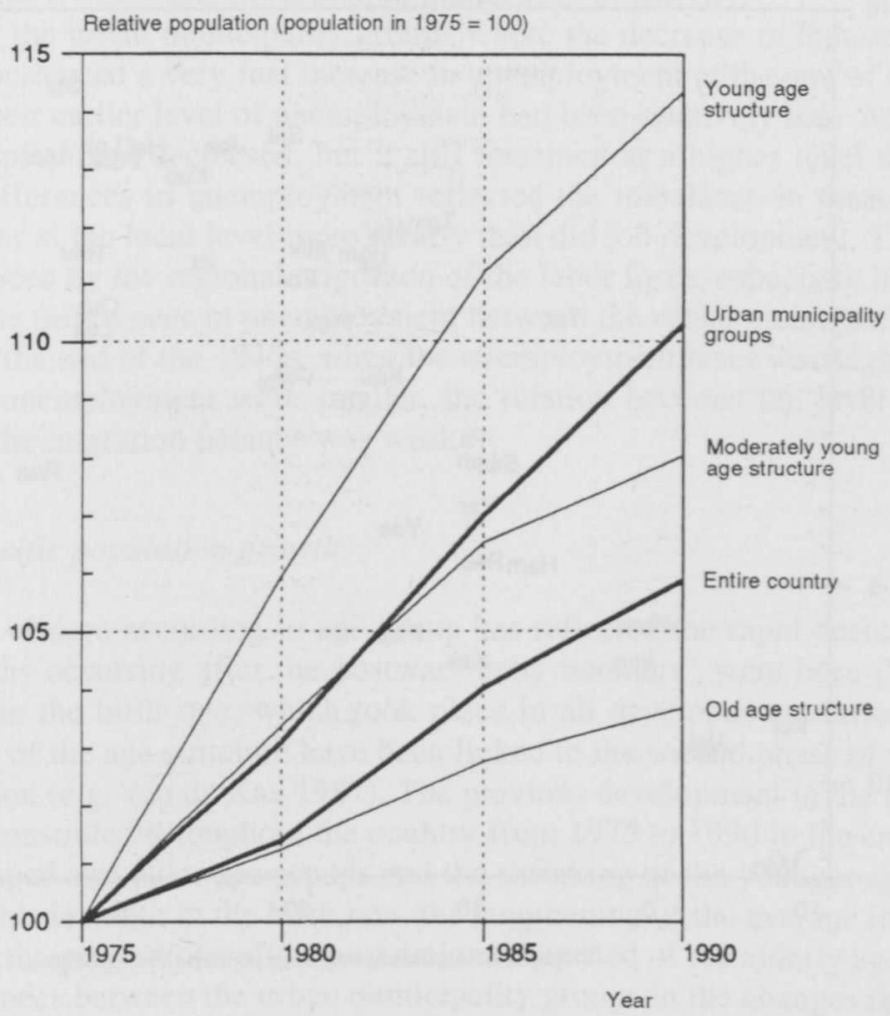

${ }^{1}$ Urban municipality groups with a young age structure: Uusikaupunki, Joensuu, Kokkola, Oulu, Kajaani, Raahe, Tornio, Rovaniemi. Urban municipality groups with a moderately young age structure: Helsinki, Porvoo, Lohja, Rauma, Pori, Lahti, Valkeakoski, Mänttä, Mikkeli, Heinola, Kuopio, Iisalmi, Jyväskylä, Pietarsaari, Seinäjoki, Kemi. Urban municipality groups with an old age structure: Loviisa, Salo, Turku, Mariehamn, Hämeenlinna, Forssa, Riihimäki, Tampere-Nokia, Kotka, KouvolaKuusankoski, Lappeenranta, Imatra, Hamina, Savonlinna, Pieksämäki, Varkaus, Vaasa

\section{Migration and the changes in the economic structure}

Migration consists of both internal migration and migration across national borders. At the end of the 1970 s migration was still relatively intense. The differences in migration balance between urban municipality groups were great, and they had an impact, through changes in the age structure, on the rate of natural increase in the $1980 \mathrm{~s}$. This was specifically a question of internal migration. The bilingual urban municipality groups situated in Northern and Southern Finland, which had experienced population loss due to migration mainly to Sweden at the end of the 1970 s, were the same areas that received immigrants in the beginning of the 1980s. In these communities the total impact on natural increase mediated by migration balanced out. 
Fig u re 5. Change (\%) in the gainfully employed population in the urban municipality groups in 1975-1990 and the total migration balance (\%) in 19751990.

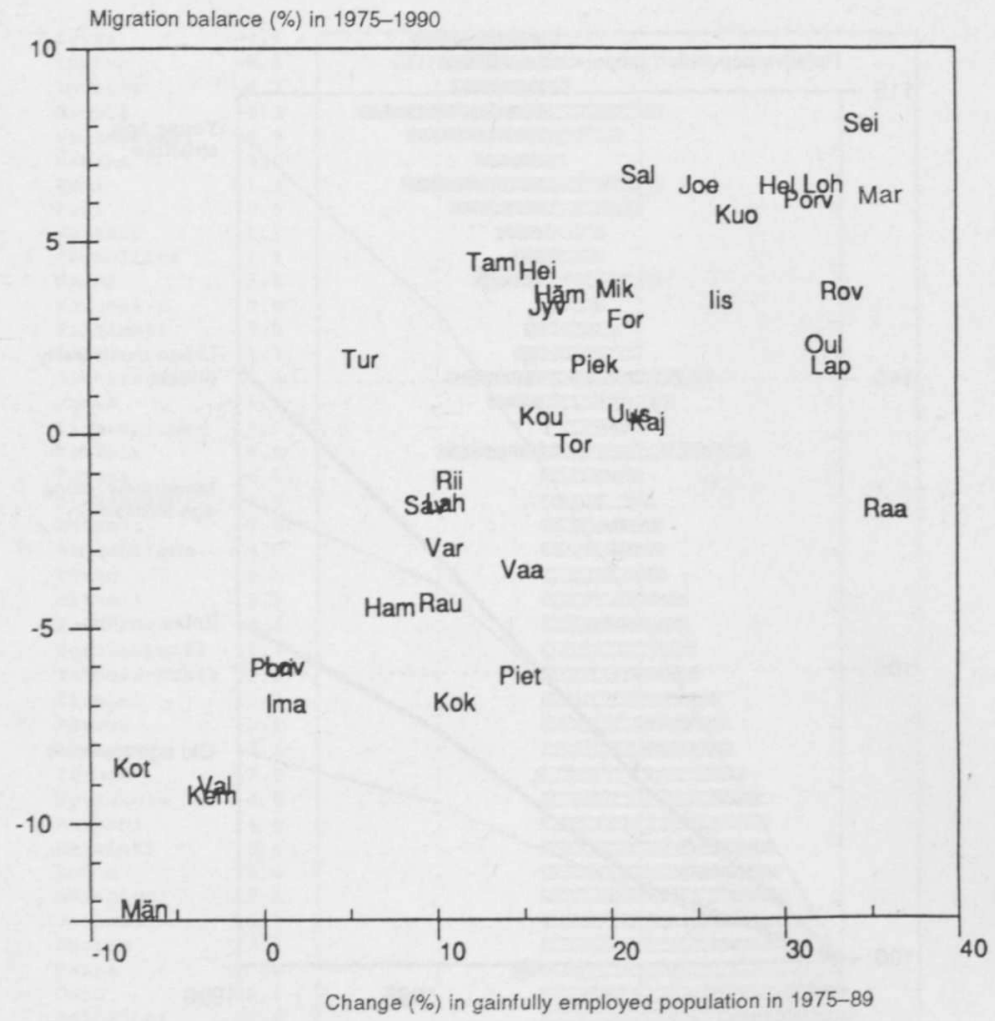

Migration depends strongly on changes in the size and structure of the labor force. Except for the end of the 1970 s, the migration gain of urban municipality groups was quite congruent with the development in the number of jobs, demonstrated by the change in the gainfully employed population (Figure 5). Primary production (agriculture, forestry, fishing and hunting) has been excluded from the analyses by industrial sector.

Migration losses were largest in the urban municipality groups where the gainfully employed population decreased, while the migration gains were largest in the communities where the labor force increased. However, many areas with a growing gainfully employed population also suffered migration losses. In many of these urban municipality groups, the proportion of the young population reaching working age was greater than average, which explains why migration pressure from these areas remained high.

Especially in the beginning of the 1980 s, the decrease in jobs was strongly correlated with deindustrialization, that is the decrease in industrial jobs. Migration losses concerned those urban municipality groups the most, where the proportion of the gainfully employed population employed in traditional industry was high. In the latter half of the 1980s, the migration balances began almost exclusively to follow the change in services; in the service sector the number of jobs grew fastest in rather large urban municipality groups with a diversified modern service structure. The decrease in industrial jobs was no longer dependent on the intensity of industry in the urban municipality groups. In some urban municipality groups with industrial production (Raahe 
and Pietarsaari, for example), jobs actually increased. The differences between the urban municipality groups in the relative change in the number of jobs increased with the centralizing tendency prevailing in the 1980s. Despite this, the order between the urban municipality groups in regard to the number of jobs they had remained almost the same, both as a whole and according to main fields of activity.

In general, the urban municipality groups where the decrease in industry was the most rapid experienced a very fast increase in unemployment at the end of the 1970 s, even though their earlier level of unemployment had been relatively low. After a peak in 1978, unemployment decreased, but it still remained at a higher level than in the mid-1970s. Differences in unemployment reflected the imbalance in the supply and demand of labor at the local level more clearly than did job development. This imbalance was balanced by the regional migration of the labor force, especially in the early 1980 s, when the differences in unemployment between the urban municipality groups were great. At the end of the 1970 s, when the unemployment level was higher but the differences in unemployment were smaller, the relation between the level of unemployment and the migration balance was weak.

\section{Age-group-specific population growth}

Population change according to age group has reflected the rapid decrease in the number of births occurring after the postwar "baby boomers" were born (Figure 6). This decrease in the birth rate, which took place in all developed countries, and the resulting aging of the age structure have been linked to the second phase of the demographic transition (e.g. van de Kaa 1987). The previous development in the number of births was demonstrated throughout the country from 1975 to 1990 in the enlargening of the middle-aged and older age groups and the shrinking of the younger age groups. In addition to the decrease in the birth rate, the lengthening of the average life expectancy increased the proportions of the population composed of the elderly age groups.

The differences between the urban municipality groups in the changes in their age structure were mainly caused by migration. As a result of the migration in the 1960 s and in 1970s, especially the middle-aged population grew in 1975-1990 more rapidly in urban municipality groups which had received migration gains (Lohja and Helsinki, for example), and more slowly in urban municipality groups which had experienced migration losses (Imatra, Hamina, Varkaus, for example) and in the areas outside urban municipality groups. Due partly to the natural increase following migration, the young age groups decreased more slowly and the older age groups more rapidly in the migration gain areas, compared to the migration loss areas. Within the urban municipality groups the age-group-specific population growth trends were realized only in the centers, for the population in the surrounding urban municipalities grew in all age groups as a result of migration gains. The population growth of the young age groups in the surrounding urban municipalities was affected by the migration of young families with children to the surrounding urban municipalities and the resulting natural increase.

\section{Future population development to the year 2010}

It is hardly possible, on the basis of past economic and population development, to determine exact developmental trends going far into the future, for the current situation in society contains many new kinds of profound processes of change. Above all, concerning the economic development of the communities, the rapid change in the in- 
Fig u re 6 . The relative population growth of the urban municipality groups by age group in 1975-90 (population in 1975 is equal to 100)

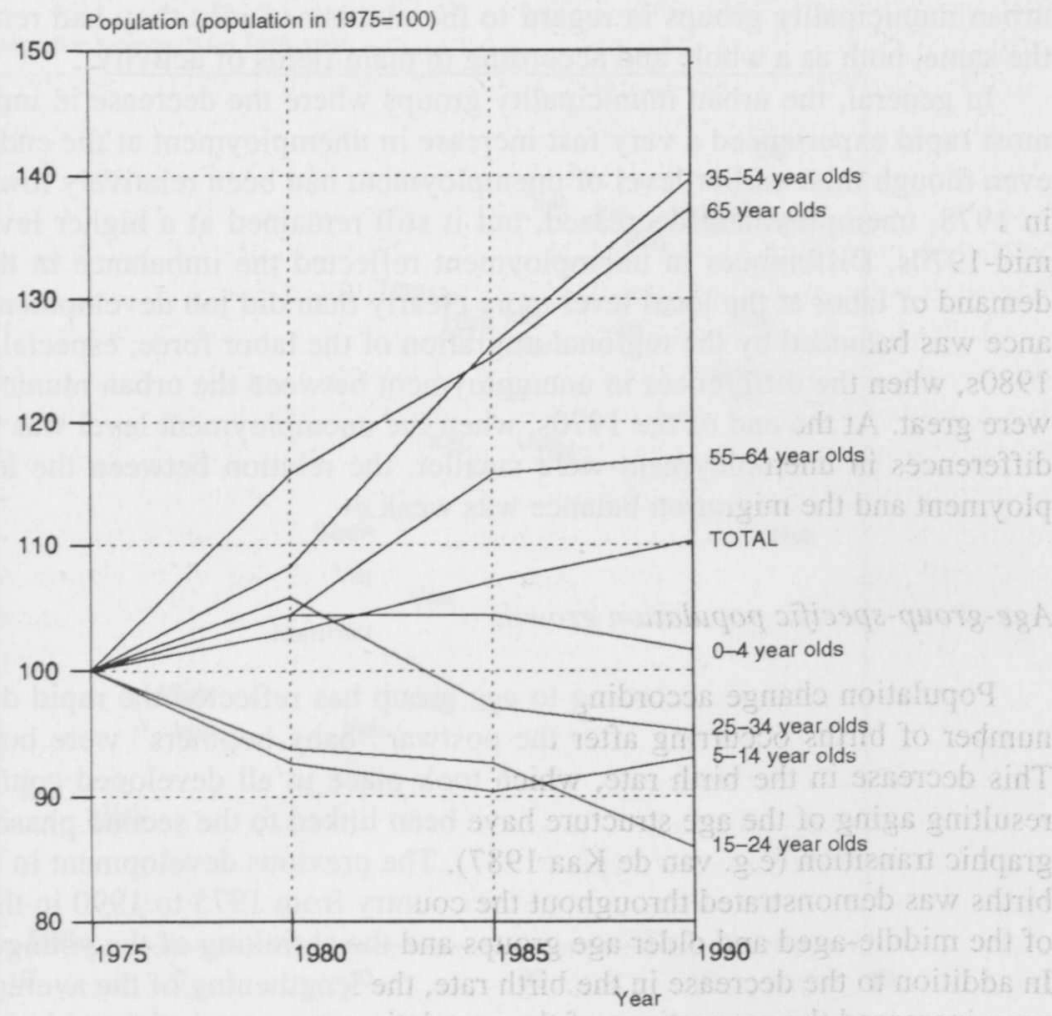

ternational and domestic competitive situation is transforming the economic basis of the communities, which will be reflected in new kinds of changes in the structure of the communities. In general, individual communities will increasingly be not only economically but also demographically dependent more on international than on domestic economic, political and social development. (cf. Kephart 1991, Lutz 1991, Champion 1992.)

\section{Population forecasts for the urban municipality groups}

The examination of future population development uses the forecasts made for each municipality by Statistics Finland (Väestö 1992:6), whose results have been reorganized to fit the units of observation in this study. The forecast contains two calculations: one describes the effects of natural increase and does not take migration in account. The other one is based on natural increase and migration.

In both calculations fertility and mortality expectations are the same.

The total fertility rate of the entire country (number of births per woman) is assumed to decline from 1.8 in 1991 to 1.72 in 1995 and after that remain at the average level (1.72) of 1987-91. The transformation has been made equally in all age groups. Although the fertility rates in the forecast have been kept stable after 1995, the number of births will decrease because of the decline in the number of women of childbearing age. 
The assumption is made that mortality will decrease up to the year 2010 , according to sex, in the age groups where it declined in the 1980s. The mortality coefficients have been kept constant in the 5-year age groups for 15-44-year-old men and 15-54year-old women and for those over 90. In Finland as a whole, the life expectancy at birth in 2010 is 73.3 for men and 80.2 for women.

The regional differences in both fertility and mortality have remained unchanged.

The relative strength and direction of migration is assumed to remain at the same level as in 1987-1989 throughout the forecast period. The number of migrants, however, will decrease as a result of the diminishing of the migrating age groups. Net immigration is assumed to decline in the near future to always one half of what it was the previous year and, starting in 1994, it is assumed to be zero.

According to the calculation including migration, the population will begin to decline in the entire country after the turn of the millennium. The population in the urban municipality groups will grow until 2010, due to the migration gains in the surrounding urban municipalities. Population losses will grow in the areas outside the urban municipality groups: migration losses and negative natural increase will grow. In the country as a whole, as in the urban municipality groups, the population over the age of 45 will grow, and age groups younger than that will decrease. The most rapid growth both absolutely and relatively by the year 2010 will be in the 60-64-year-old age group, as the baby boomers reach this age. The oldest among the baby boomers will have reached the age of 65 by this time. (Figure 7)

Among the younger age groups the largest decrease will be among those under the age of 15 and among the young adults (aged 25-34). The slowest decrease will be in the 15-24-year-old population. The $35-54$ year olds will begin to decrease at the same time as the total population.

The age structure and natural increase in the urban municipality groups are determining factors in their future population development. Differences in natural increase, again, depend strongly on differences in the age structure of the population (see Table 1). The natural increase in urban municipality groups with a young population is clearly the most positive (7.6\%) on the average, according to the forecast excluding migration made by Statistics Finland, and growth in the urban areas with an old population the most negative $(-5.0 \%)$. These extreme communities are represented, for example, by Tornio and Kotka in Figure 8 . In the urban municipality group of Tornio the base of the population pyramid is broader, but the peak is narrower than in the urban municipality group of Kotka. The baby boomers are visible in the pyramids as out-reaching bars in the middle-age group. In the urban municipality group of Tornio, the evenness of the population pyramid for the year 2010, begins to resemble the current population pyramid of the Kotka urban municipality group.

In addition to the community groups which differ most from each other in regard to their age structure, there are also clear differences in natural increase between the other two groups. In urban municipality groups with a moderately young population, the average natural increase is positive $(4.7 \%)$, but in the urban municipality groups with a moderately old population, it is slightly negative $(-0.9 \%)$. Because the differences in age structure and natural increase are significant, the migration balances should be substantial and divergent from recent development, so that they would change the main differences existing in population development.

The impact of migration on regional population development is greater, the more limited the region's population. (Cf. Clark 1991.) In an individual urban municipality group, the effect of even minor migration gains or losses on population growth (or the aging of the population's age structure) may be marked, because at the same time the age structure will be aging in general and natural increase slowing down. Migration loss conforming to the calculation including migration would stop population growth 
F i g u r e 7. Relative population growth in the urban municipality groups by age groups in 1990-2010 (the population in 1990 is equal to 100) according to the calculation including migration

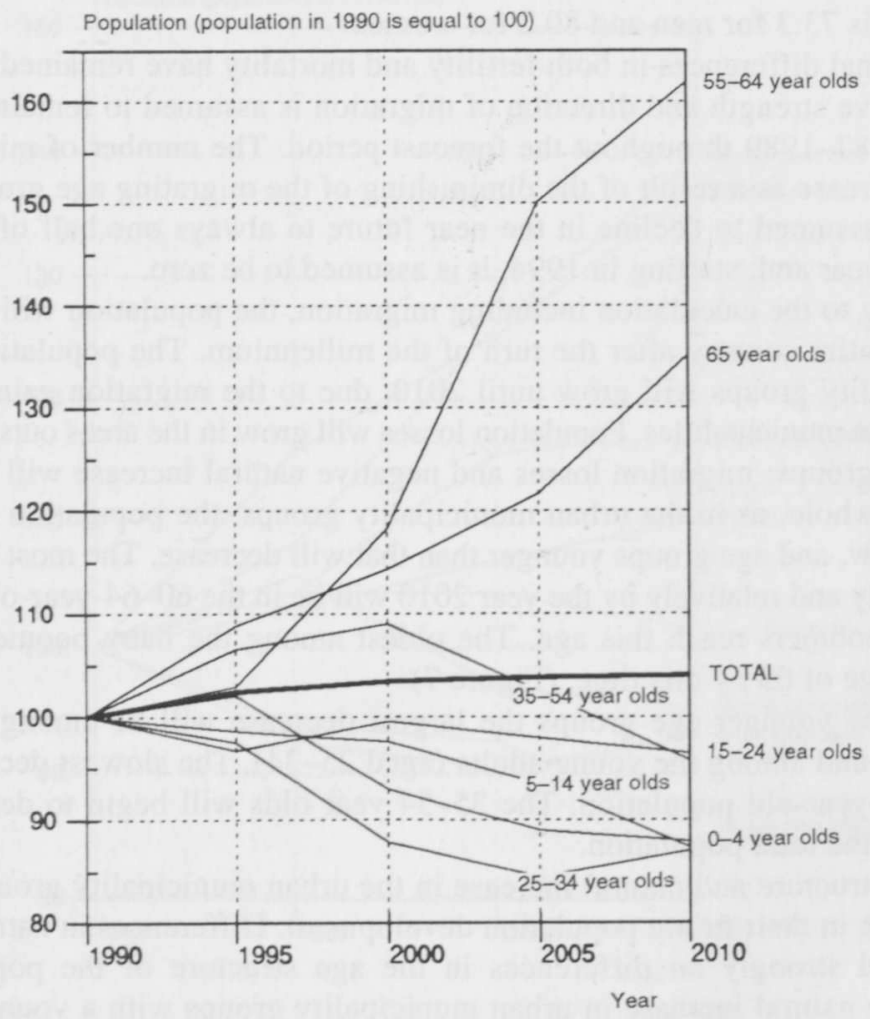

Source: The calculation including migration (Statistics Finland, Population 1992:6)

in the urban municipality groups of Tornio and Raahe, for example. On the other hand, in small urban municipality groups racked by migration loss, where natural increase is slow, the impact of migration gains diverging from the predicted trend calculation might be significant.

The calculation including migration predicts that migration will be at the 1987-89 level and net migration will be zero from 1994 on. In the current transitional phase of society it is very unlikely, however, that future migration would continue to conform to development prevailing in the boom years of the 1980 s. Already during the current economic recession, the narrowing of differences in unemployment has slowed down internal migration. On the other hand, immigration to Finland has been greater than predicted.

\section{Job development and migration}

The migration of the population has mainly been regional movement of the labor force, which has resulted from the regional location of industrial activity and the relocation of jobs. The regional mobility of the labor force has been the result of the quantitative, qualitative and regional variation in the supply and demand of labor (see, for 
Fig u re 8 . The population pyramids of the urban municipality groups of Tornio (young age structure) and Kotka (old age structure) in 1990 and 2010 according to the self-sufficiency forecast exluding migration

1990

The urban municipality group of Tornio

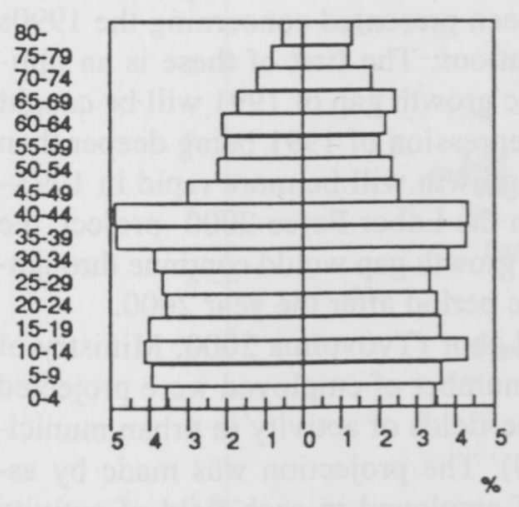

The urban municipality group of Kotka

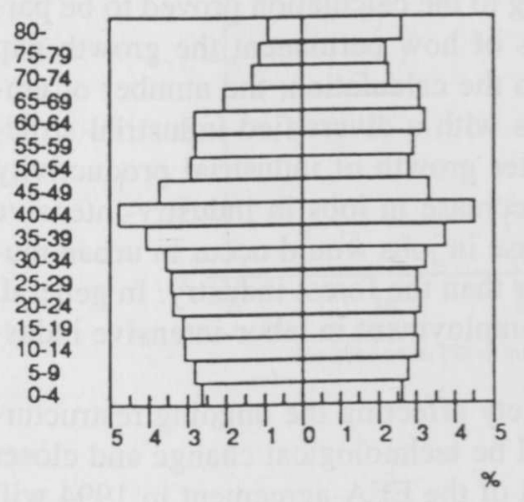

2010

The urban municipality group of Tornio

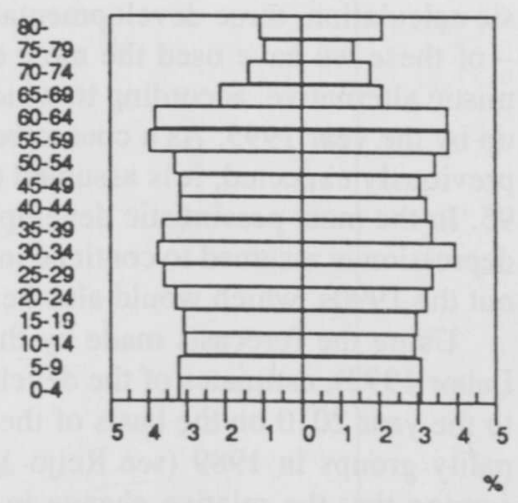

The urban municipality group of Kotka

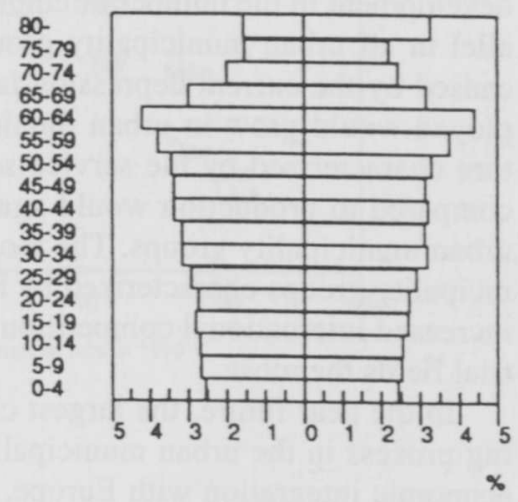

example, Korkisaari 1991). Future migration in any given region can be assumed to depend mainly on labor demand factors, if the supply of labor remains about the same.

The demographic supply of labor is roughly depicted, for example, by the ratio of age groups joining the labor force to those leaving it (Valkonen 1991). The demographic supply of labor in relation to the population can be assumed to be about the same in urban municipality groups, where the age structure is the same. The younger the age structure, the greater the supply of labor. Without taking into account possible variation in labor force participation, the simple assumption can be made that in urban municipality groups with a similar age structure, labor force mobility and migration to the region depend ultimately on the quantitative demand for labor in each individual urban municipality group - a demand which is linked with the economic development of that region.

The Labor Force 2000 -project started by the Ministry of Labor has made a forecast of the development in the number of employed up to the year 2030 (Työvoima 2000), which is based on estimates of the growth of the entire country's production 
and the development of the number of the gainfully employed in various fields of activity. The calculation is considered a goal-directed basic calculation for the first half of the 1990s, which can be attained with a successful economic policy. The Ministry of Labor (1992) has reexamined the calculation up to the year 2000, due to an unexpectedly serious depression. The effect of the depression on the demand for labor depends not only on the depth and length of the depression, but also on how permanent the growth gap caused by the depression will be. In alternative calculations to the basic calculation, three developmental trends have been presented concerning the $1990 \mathrm{~s}$ - of these we have used the most extreme calculations. The first of these is an optimistic alternative, according to which the economic growth gap of 1991 will be caught up by the year 1995. As a counterbalance to the depression of 1991 being deeper than previously expected, it is assumed that economic growth will be more rapid in 199395. In the most pessimistic developmental trend in the Labor Force 2000 -project, the depression is assumed to continue in 1991-95. The growth gap would continue throughout the 1990s, which would also be reflected in the period after the year 2000 .

Using the forecasts made by the Ministry of Labor (Työvoima 2000; Ministry of Labor 1992), estimates of the development of the number of employed were projected to the year 2010 on the basis of the structure of the fields of activity in urban municipality groups in 1989 (see Reijo 1993) (Figure 9). The projection was made by assuming that the relative change in the number of employed in each field of activity would be the same in all urban municipality groups as in the country as a whole. The development in the number of employed according to the calculation proved to be parallel in all urban municipality groups, regardless of how permanent the growth gap caused by the current depression is. According to the calculation, the number of employed would grow in urban municipality groups with a diversified industrial structure characterized by the service sector. The faster growth of industrial productivity compared to production would again lead to a decrease in jobs in industry-intensive urban municipality groups. The most rapid decrease in jobs would occur in urban municipality groups characterized by industries other than the forest industry. In general, increased international competition will weaken employment in labor-intensive industrial fields the most.

In the near future, the largest changes in society affecting the ongoing restructuring process in the urban municipality groups will be technological change and closer economic integration with Europe. The inaugural of the EEA-agreement in 1994 will increase competition and make the free movement of labor possible. In addition, it will prohibit support to enterprises that distorts competitional status. (Agreement of the European Economic Area 1992.) The regional effects of joining the EU would focus, in addition to the above, specifically on regional policy-based support systems carried out in the public sector. (Government bill 1992.)

In the largest urban municipality groups the infrastructure (entrepreneurial services, transportation networks etc.) are developed, the supply of labor is qualitatively and quantitatively diversified and the basis for production demand is broader. Therefore, the preconditions they have for competitive and innovative economic activity are probably better than in urban municipality groups with a small population base. Enterprises strive to maximize agglomeration benefits such as this. Usually the existing infrastructure can be changed quite slowly, so that it determines, to a large degree, the framework to which the economic structural changes must conform, at least in the short term (e.g. Lumijärvi 1990). Therefore, it can be assumed that jobs and the population will increasingly concentrate in the largest urban areas.

The Labor Force 2000 -projection assumes that with the enactment of the EEAagreement, migration from Finland toward Western Europe will be about the same as immigration from there to Finland (Työvoima 2000). On the other hand, a larger mi- 
Fi g u r e 9. The proportion of industrial jobs in urban municipality groups of all jobs in 1989 and change (\%) in jobs in 1989-2010, not including agriculture and forestry, as a projection made according to the forecast of the Ministry of Labor (Työvoima 2000)

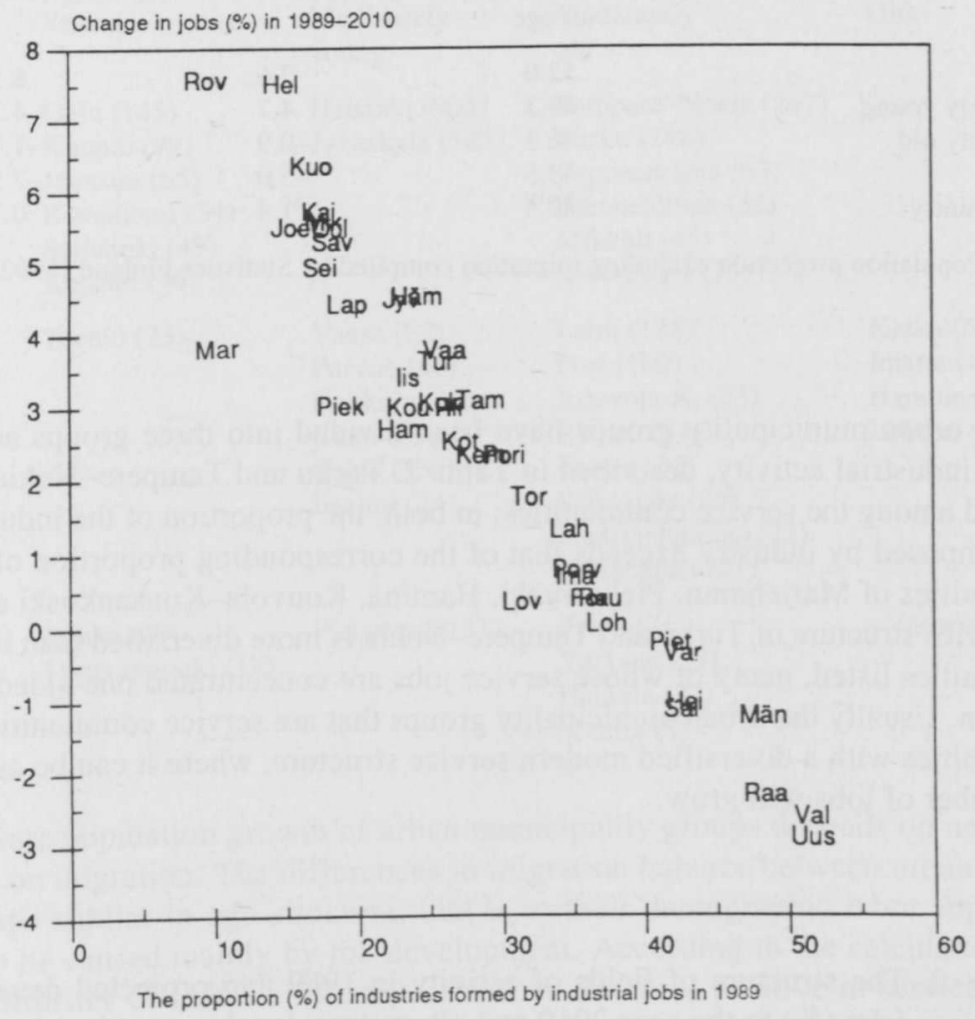

gration flow can be expected from Eastern Europe. Migration desires also exist in the developing countries. It is most likely that potential migration gains would focus on areas with concentrations of the economy and population, as has occurred in the EU countries (cf. Champion 1992.)

\section{Development types of urban municipality groups}

Above we have examined two structural factors in the urban municipality groups: the age structure and the structure of the fields of industrial activity, which can be assumed to have a strong impact on the future development of urban municipality groups. These dimensions were used (Reijo 1993) to classify urban municipality groups according to type of future development.

The urban municipality groups were divided into four types according to the age structure of 1990; the features of the types are described in Table 1. In urban municipality groups with a young age structure, the population and also the working-age population would grow by $8-9$ percent, disregarding the effect of migration, while in the urban municipality groups with an old age structure, both the entire population and the working-age population would decrease. 
$\mathrm{T}$ a b l e 1. The relative change (\%) in population and working-age population in 1990 2010 in urban municipality groups with different age structures according to the calculation excluding migration

$\begin{array}{lccc}\text { Age strucure } & \begin{array}{c}\text { Population } \\ \text { under 35 years } \\ \text { of age }\end{array} & \begin{array}{c}\text { Entire } \\ \text { population }\end{array} & \begin{array}{c}\text { Working-age } \\ \text { population }\end{array} \\ \text { Young } & 52.0 & 7.6 & 8.5 \\ \text { Moderately young } & 49.3 & 4.7 & 4.2 \\ \text { Moderately old } & 46.3 & -0.9 & -1.7 \\ \text { Old } & 43.5 & -5.0 & -7.5 \\ \text { Entire country } & 47.4 & 1.4 & 0.7\end{array}$

Source: Population projection excluding migration compiled by Statistics Finland (1992)

The urban municipality groups have been divided into three groups according to field of industrial activity, described in Table 2. Turku and Tampere-Nokia have been included among the service communities; in both, the proportion of the industrial structure composed by industry exceeds that of the corresponding proportion of the mixed communities of Mariehamn, Pieksämäki, Hamina, Kouvola-Kuusankoski and Iisalmi. The service structure of Turku and Tampere-Nokia is more diversified than in the mixed communities listed, many of whose service jobs are concentrated one-sidedly in transportation. Usually the urban municipality groups that are service communities are large communities with a diversified modern service structure, where it can be assumed that the number of jobs will grow.

T a b le 2. The structure of fields of activity in 1989 and projected development of jobs (\%) to the year 2010 and alternative development trends in the 1990 s

$\begin{array}{lcccc}\begin{array}{l}\text { The structure } \\ \text { of activity }\end{array} & \begin{array}{c}\text { Industrial } \\ \text { proportion }^{\mathrm{a}}\end{array} & 2010^{\mathrm{b}} & 2000^{\mathrm{b}} & \begin{array}{c}\text { To the year } \\ \text { developmental } \\ \text { trend }^{\mathrm{c}}\end{array}\end{array}$

$\begin{array}{lccccc}\begin{array}{l}\text { Service } \\ \text { communities }\end{array} & 18.6 & 5.3 & 5.3 & -1.4 & 4.9 \\ \begin{array}{l}\text { Mixed } \\ \text { communities }\end{array} & 27.3 & 2.0 & 3.5 & -2.9 & 4.0 \\ \begin{array}{l}\text { Industrial } \\ \text { communities }\end{array} & 43.5 & -1.5 & 2.3 & -3.9 & 3.6 \\ \text { Entire country } & 24.9 & 3.6 & 4.3 & -2.6 & 4.3\end{array}$

a) not including primary production

b) Basic calculation. Ministry of Labor's basic calculation (Työvoima 2000)

c) Ministry of Labor's (1992) pessimistic and optimistic developmental trends starting in 1991 for job development following the unexpectedly deep depression.

Classifying the urban municipality groups according to both structural variables at the same time results in a 12-class typology (Table 3). One of the categories in the typology is empty (service communities with an old age structure) and three types consist of only one community. The highest number of communities is found in the category of mixed communities with a moderately old population. 
T a b l e 3. Urban municipality groups according to their age structure in 1990 (proportion of the population under 35 years of age) and the structure of fields of activity (proportion of industries composed by industry) in 1989, population in 1990 (thousands) in parentheses

\begin{tabular}{|c|c|c|c|c|}
\hline \multirow{2}{*}{$\begin{array}{l}\text { Structure of } \\
\text { fields of } \\
\text { activity }\end{array}$} & \multicolumn{3}{|c|}{ Age structure of the population } & \multirow{3}{*}{ Old } \\
\hline & Young & $\begin{array}{l}\text { Moderately } \\
\text { young }\end{array}$ & $\begin{array}{l}\text { Moderately } \\
\text { old }\end{array}$ & \\
\hline $\begin{array}{l}\text { Service } \\
\text { communities }\end{array}$ & $\begin{array}{l}\text { Oulu (145) } \\
\text { Kuopio (99) } \\
\text { Joensuu (65) } \\
\text { Rovaniemi (54) } \\
\text { Seinäjoki (49) } \\
\text { Kajaani (36) }\end{array}$ & $\begin{array}{l}\text { Helsinki }(905) \\
\text { Jyväskylä (105) }\end{array}$ & $\begin{array}{l}\text { Tampere-Nokia (267) } \\
\text { Turku (248) } \\
\text { Lappeenranta (63) } \\
\text { Hämeenlinna (55) } \\
\text { Mikkeli (45) } \\
\text { Savonlinna (35) }\end{array}$ & \\
\hline $\begin{array}{l}\text { Mixed } \\
\text { communities }\end{array}$ & Tornio (23) & $\begin{array}{l}\text { Vaasa }(82) \\
\text { Porvoo }(46) \\
\text { Kokkola }(39) \\
\text { Kemi }(39) \\
\text { Lohja (33) } \\
\text { Iisalmi (24) }\end{array}$ & $\begin{array}{l}\text { Lahti (128) } \\
\text { Pori (100) } \\
\text { Kouvola-K. (73) } \\
\text { Rauma (51) } \\
\text { Forssa (31) } \\
\text { Riihimäki (25) } \\
\text { Maarianhamina (22) } \\
\text { Pieksämäki (21) }\end{array}$ & $\begin{array}{l}\text { Kotka (62) } \\
\text { Imatra (40) } \\
\text { Hamina (23) } \\
\text { Loviisa (12) }\end{array}$ \\
\hline $\begin{array}{l}\text { Industrial } \\
\text { communities }\end{array}$ & $\begin{array}{l}\text { Raahe (29) } \\
\text { Uusikaupunki (18) }\end{array}$ & Pietarsaari (33) & $\begin{array}{l}\text { Salo (37) } \\
\text { Varkaus (33) } \\
\text { Heinola (22) } \\
\text { Mänttä (8) }\end{array}$ & -Valkeakoski (22) \\
\hline
\end{tabular}

The future population growth of urban municipality groups depends on natural increase and on migration. The differences in migration balance between urban municipality groups similar in age structure, that is in their demographic labor supply, are assumed to be caused mainly by job development. According to the calculation made using the Ministry of Labor's forecast, it will be the most positive in service-intense urban municipality groups with a fairly large population and the most negative in industry-intense urban municipality groups with a fairly small population (Table 2).

The most rapid natural increase, according to the calculation, will be found in urban municipality groups with a young age structure situated in Central and Northern Finland and traditionally areas of high fertility. In these areas, the concentrations of economic development and assumed target areas of related labor migration are the urban municipality groups of Oulu, Kuopio, Joensuu, Rovaniemi and Seinäjoki as well as Kajaani, the provincial center of Kainuu. Migration flows will be directed to these urban municipality groups, and as a result, population growth will be rapid. The large supply of working-age population caused by a high natural increase may partly decrease migration gains. Urban municipality groups with stable or recessive job development and thus with possible migration losses are the industrial communities of Tornio, Raahe and Uusikaupunki. It will depend on the size of migration losses, whether fertility will compensate for the growing disadvantageousness of the population's age structure regarding the birth rate, and whether the total population growth will remain positive, in general.

A decrease in the population is probable in the urban municipality groups with an old age structure, where natural increase has been very negative: the excess number of deaths compared to births will continue to increase. It is predicted that the status of the urban municipality group of Valkeakoski will be the worst among the urban municipality groups in the study, in regard to its economic outlook and thus also its migration losses. The population losses in the other urban municipality groups situated 
in Southeastern Finland are mainly due to negative natural increase. The migration losses may decrease because the proportions of the population most likely to migrate are relatively small, so that an excess supply of labor may not necessarily arise.

On the basis of the typology, the differences already existing in demographic development would increase between the extreme groups (urban municipality groups with a young age structure, a diversified industrial structure and a large population vs. urban municipality groups with an old population, an industry-intense industrial structure and a small population). Migration gains will increase the rate of population growth in areas with a young age structure and migration losses will increase the rate of population loss in areas with an old population. In urban municipality groups with a moderately young or moderately old age structure, migration might even out the differences caused by natural increase.

The onset of the growth in the differences in demographic development described above occurred many decades ago. A definite demographical-historical point of departure is found in post-World War II development. The proportion of the population formed by the postwar large age groups was highest in Northern and Eastern Finland. The possibilities for earning a living were not sufficient for these large age groups entering the labor market in the early 1960s, which led to out-migration from these areas, continuing into the 1970s. Especially in Eastern Finland, mechanization decreased jobs in primary production and caused migration pressure. At the same time, the large centers in Southern Finland and Sweden, where the migration flows were directed to, offered job opportunities in the widening service sectors. (e.g. Katajamäki 1988). In the migration phase, population development began increasingly to specialize according to region. In Eastern Finland migration losses led to the aging of the population structure, the slowing down of natural increase and finally to the aging of the population. In Northern Finland high fertility kept the population's age structure young and natural increase rapid, despite migration losses. The rapid total growth of the centers in Southern Finland was a direct result of migration and an indirect result of the natural increase resulting from migration.

The increase in the service intensity of the industrial structure has been related to the youth of the population's age structure; generally, in urban municipality groups where the age structure of the population is young, jobs in the service sector (education, health care), in particular, increased rapidly (Reijo 1993). Broad reforms in education, health care, social welfare and other service sectors of society in the 1960s70 s made it possible to answer to the needs caused specifically by the young population; in particular, public income transfers and public consumer expenditures increased. Income transfers were directed to the young population (including child allowances, maternity benefits), whose consumption demand increased.

Because the consumption of services and goods is dependent on the phase of the lifespan, the municipalities in the urban municipality groups with a young age structure invested more than others on, for example, family housing, day-care centers and schools. Increasing demand and investment projects then created consequent jobs and attracted both more enterprises and more labor to the area. For example, in the urban municipality groups in Northern Finland suffering from migration losses, areas such as Oulu and Rovaniemi, the migration losses began to turn into migration gains. Exceptional urban municipality groups in Northern Finland were industrial communities such as Kokkola, where migration losses continued along with the dismantling of industrial jobs - in both metal manufacturing and in the textile and clothing industries. In addition to the population's young age structure, the size of the population has been a central factor in job development. The entrepreneurial services in the commercial and financing sectors, especially, showed definite market directedness toward urban municipality groups with a large population (Reijo 1993). 
The construction of urban municipality groups has naturally been related to population growth. Housing construction was active after the 1970s in urban municipality groups with rapid population growth, where the proportion of new housing in the entire housing base was large, especially in Northern Finland (Seppelin 1992). Because the birth rate in in the upper part of Northern Finland was high, household size and housing space were larger and large family housing increased more rapidly.

\section{Future population development and housing and construction needs}

As was described above, future general trends in population development are the cessation of population growth and the aging of the population. Because the age groups reaching the age when families are formed are decreasing, assumedly the demand for new housing will diminish. On the other hand, the demand for housing will increase with the growth in housing space and decrease in average household size and the regional imbalance in population development and the housing base.

The varying development of housing needs in urban municipality groups is illustrated in Table 3 . In urban municipality groups with an old or moderately old population, housing becomes available through deaths more rapidly than new people needing housing join the housing market. In general, the housing needs of elderly inhabitants will be emphasized. Even though the housing base is older, a large share of it can be considered liveable with relatively small additional investments. The need for construction depends on the migration balance, in addition to the age structure. Large urban municipality groups with a diversified structure of industrial activity (for example, Tampere-Nokia, Turku) will have migration gains and those moving into the area will maintain the demand for new housing, including family housing. In urban municipality groups with a small population and a one-sided industrial structure (for example, Valkeakoski and Mänttä) migration losses will increase the amount of newly empty housing.

Although housing production in urban areas with a moderately young or young age structure has been active in the last few decades, the housing base will probably not be sufficient for the new age classes needing their first housing, who, quantitatively, will for a long time exceed the amount of housing being released through deaths. The need for both small housing for young people and large family housing will continue to be great. The level of fertility will affect the size of family housing: in the urban municipality groups in Northern Finland, where fertility is higher, larger family housing will be needed than in the urban areas in Southern Finland, where fertility is low. In communities with a young age structure, the old age groups are also growing and this requires investments in housing for the elderly. The need for the construction of new housing will grow markedly in urban areas still experiencing migration gains (for example, Helsinki, Oulu). Even in urban municipality groups with migration loss and a young age structure, the demand for new housing will remain high (for example, Raahe, Pietarsaari), although relatively smaller than in the areas of migration gain.

\section{Factors of uncertainty in predicted development}

Especially in the current situation, forecasts concerning development in society are uncertain even in the short term. Of the forecasts presented above, the least uncertain are the calculations concerning self-sufficiency development, which are mainly based on already existing differences in age structures.

The greatest lack in the population projection compiled by Statistics Finland (Väestö 1992:6), used as a basis for the calculations, is that it has assumed that emigration 
and immigration will be balanced from 1994 on. At the moment it seems probable that Finland will have migration gain, a large share of which may be refugees and asylum seekers. It is impossible, however, to estimate how large immigration will be. If immigration were directed evenly to all areas, it would not have any marked effect regarding the predicted differences. It is probable, however, that the migration gain will concentrate only in certain areas.

Another uncertain factor in the calculations presented concerns the assumptions concerning the development of the size of the labor force. The calculations are based on the assumption that the development forecasts made by the Ministry of Labor specific to each industrial field will be realized.

The forecast of the Ministry of Labor (Työvoima 2000) is based on the growth of industrial production leading to a decrease in the labor force. On the other hand, in the service sector, the labor force would increase by almost 200,000 persons by the year 2010. In the public sector the rise would be 11 percent and in finance and insurance over 25 percent. In light of recent developments, such a forecast seems incorrect. It is very possible that especially in the public domain, and particularly in finance and insurance, the labor force will diminish markedly and the level of unemployment will also remain high in service-intensive urban municipality groups. Then the labor force would not increase as predicted in service communities or in large urban municipality groups, with the result also that their population growth would be smaller than predicted. Classifying the urban municipality groups according to the typology in Table 3 is based on the automatic assumption that the relative employment development of each field of activity is the same throughout the country. This is not necessarily so, of course.

\section{Reactions to slower growth}

On both the national and local level, population growth has been considered a selfevident aim and a sign of success, while a decrease in population has been seen as failure. This way of thinking has led to strong competition between different parts of the country and between different municipalities within any given area. Competition may also have had a positive impact, but at the same time it has led to excessively large investments and an uneconomic structure of society.

When the growth of the country's and also the urban municipality groups' joint population begins to slow down, thinking which emphasizes population growth may lead to even more intense competition. Another possibility is that there will be a change in the way people think and people will give up the idea that population growth is a measure of success. The well-being of people living in growing communities will not necessarily be better than that of people living in communities with a diminishing population. A growing population may even be a poorer alternative than a stable one. In a growing population, merely maintaining the quantitative level of services requires planning and investments. Communities, where the population is not growing, need fewer investments in services, housing and other infrastructure. They can concentrate on improving services and the quality of life. Because of the growth in the old age groups, services for the elderly will cause increasing expenditures everywhere, however, but correspondingly savings in expenditures on the young age classes.

If too distinct a separation occurs among the urban municipality groups into growing and diminishing areas, the result will be the incomplete and uneconomical use of investments in housing and infrastructure in areas experiencing population loss and overlapping investments in growing areas. In this situation, balanced development would be beneficial to the whole. It is difficult, however, to decide what means to use to at- 
tain more balanced development. One possibility is to develop a system corresponding to the former regional policy support, where problematic communities experiencing population loss would receive support.

One of the few public measures, which could possibly balance future population development and investments between urban areas, is to locate refugees and immigrants to urban municipality groups with an old age structure. Urban municipality groups receiving refugees are required, however, to have relatively favorable economic growth prospects and labor force demand, for this measure to have more permanent consequences, and so migration flows would not begin to focus anew toward population concentrations. The placement of refugees in areas with otherwise decreasing population with relatively small expenditures is made possible by a sufficiently developed infrastructure and housing base, which have not been in full use because of the decreasing and aging of the population.

\section{References}

Andersson, H., Valkonen,T., Lahti, P., Virkkala, S., Rannikko, P., Kostiainen, R., Vuolanto, T., Pakarinen, T. (1991) Prospects for Finnish Localities. A conceptual framework of a multidisciplinary programme of research. Information 1. Helsinki: Ministry of Environment.

Anttalainen, M.-L. (1990) Yhdyskuntien väestönkehitys ja taloudellinen rakennemuutos: urbaanit päivittäisalueet ja niiden väestökehitys (Community population development and the economic structural change: urban localities and their population development). Working Papers No. 52. Helsinki: University of Helsinki, Department of Sociology.

Champion, A. G. (1992). Urban and regional demographic trends in the developed world. Urban Studies 29(3/4):461-482.

Clark, R.L. (1991) Ageing urban populations and the economic vitality of the cities of the world. In: Ageing and Urbanisation, pp. 239-246. United Nations: New York.

Hallituksen esitys 1992. (Government bill 1992) (1992) Euroopan talousalueen perustamiseen liittyvien sopimusten eräiden määräysten hyväksyminen. (Passing certain regulations concerning agreements related to the foundation of the European Economic Area). HE 95/1992.

Kaa, D. J. van de. (1987) Europe's second demographic transition. Population Bulletin 42(1):1-57.

Katajamäki, H. (1988) Alueellisen työnjaon muotoutuminen Suomessa. (The formation of regional labor distribution in Finland). Julkaisuja n:o 3. Turku: Turun yliopisto, maantieteen laitos.

Kephart, G. (1991) Economic restructuring, population redistribution and migration in the United States. In: Urban Life in Transition, edited by M. Gottdienen and C.G. Pickvance. Urban Affairs Annual Reviews, Volume 39, pp. 12-34. Sage Publications: Newbury Park.

Korkiasaari, J. (1991) Liikkuvuus ja rakennemuutos. (Mobility and the structural transition). Työpoliittinen tutkimus No. 11. Helsinki: Työministeriö.

Lumijärvi, T. (1990). Euroopan yhdentyminen ja aluepolitiikka. (The integration of Europe and regional policy). Aluepoliittisia tutkimuksia ja selvityksiä n:o 3 . Helsinki: Sisäasainministeriö.

Lutz, W. ed. (1991) Future Demographic Trends in Europe and North America: What Can We Assume Today. London: Academic Press.

Reijo M. (1993) Suomalaisten kaupunkiyhdyskuntien väestönkehitys 1975-2010. (The population development of the Finnish urban areas in 1975-2010. Suomen Väestötieteen yhdistyksen julkaisuja, no. 13. Helsinki.

Reijo, M. and Valkonen, T. (1991) Yhdyskuntien väestönkehitys ja taloudellinen rakennemuutos:syntyvyys kaupunkiyhdyskunnissa 1976-87. (Community population development and the change in the economic structure: fertility in urban areas in 1976-87). Working Papers No. 55. Helsinki: University of Helsinki, Department of Sociology.

Reijo, M. and Valkonen, T. (1992) Yhdyskuntien väestönkehitys ja taloudellinen rakennemuutos: kuolleisuus kaupunkiyhdyskunnissa 1976-87. (Community population development and the change in the economic structure: mortality in urban areas in 1976-87). Unpublished manuscript.

Seppelin, M. (1992) Asuntokuntien koko ja asuntokannan rakenne kaupunkiyhdyskunnissa 1975-89. (Household size and the housing base in urban areas in 1975-89). Working Papers No. 56. University of Helsinki, Department of Sociology.

Sopimus Euroopan talousalueesta sekä siihen liittyvät muut sopimukset (Agreement on the European Economic Area). Osa I. (1992). Ulkoasiainministeriön julkaisuja 6. Helsinki: Ulkoasiainministeriö. 
Ministry of Labor. (1992) Laman vaikutus työvoimatilanteeseen 1990-luvulla erityisesti teollisuuden kannalta (Impact of the depression on the labor force situation in the 1990s especially in regard to industry). Unpublished calculations.

Työvoima 2000 (Labor force 2000) (1991) Työvoiman kysynnän ja tarjonnan kehitys vuoteen 2000 ja arvioita vuoteen 2030. (The development of labor force demand and supply to the year 2000 and estimates to the year 2030). Helsinki: Työministeriö.

Valkonen, T. (1991) Demografiset tekijät ja muuttoliike. (Demographic factors and migration). In: Maassamuutto ja yhdentyvä Eurooppa. Muuttoliikesymposium 1990. (Internal migration and integrating Europe: migration symposium 1990), edited by Olavi Koivukangas, Raimo Narjus and Timo Virtanen, pp.142-149. Siirtolaisuustutkimuksia A 15. Turku: Siirtolaisuusinstituutti. Institute of Migration A 15. Turku. p. 142-149.

Väestö 1992:6 (Population 1992:6) Väestöennuste kunnittain 1991-2020. (Population projection by municipalities for 1991-2020). Helsinki:Statistics Finland. 